\title{
THE SHIFT OF KARO ADAT INHERITANCE LAW ON DAUGHTER AND WIDOW'S PORTION ${ }^{\Omega}$
}

\author{
Rosnidar, Afrit and Zulkifli \\ Faculty of Law Universitas Sumatera Utara \\ oni_usu@yahoo.com
}

\begin{abstract}
Supreme Court Verdict No. $179 \mathrm{~K} / \mathrm{Sip} / 1961$ states that son and daughter have equal portion of inheritance. Then, the Supreme Court Verdict No. $100 \mathrm{~K} / \mathrm{Sip} / 1967$ stated that a widow is the recipient of her deceased husband's legacy. The research formulates the following questions; What is the status of a daughter and widow in relation to the inheritance of her parent/ husband legacy in Karo communities after the Supreme Court Verdict No. 179 K/Sip/1961 and Supreme Court Verdict No. $100 \mathrm{~K} / \mathrm{Sip} / 1967$ that have been implemented? How does the inheritance law develop recently? These questions will be addressed empirically by a descriptive analytical method. The shift of adat inheritance law occurs post Supreme Court Verdict No. $179 \mathrm{~K} / \mathrm{Sip} / 1961$ which puts the equal right for both son and daughter. Besides, the post Supreme Court Verdict No. $100 \mathrm{~K} / \mathrm{Sip} / 1967$ states the widow is the recipient of her deceased husband's legacy.
\end{abstract}

Keywords : Karo adat inheritance law, daughter/widow, Supreme Court Verdict

Abstrak

Putusan MA No. $179 \mathrm{~K} / \mathrm{Sip} / 1961$ memutuskan bagian anak lelaki sama dengan anak perempuan, adapun Putusan MA No. 100 K/Sip/1967 memutuskan janda adalah ahli waris. Permasalahan penelitian ini: Bagaimana Kedudukan Anak Perempuan dan Janda Terhadap Harta Warisan Orang Tuanya/ Suaminya Pada Masyarakat Karo Pasca Putusan Ma Nomor 179 K/Sip/1961 dan Putusan MA Nomor 100 $\mathrm{K} / \mathrm{Sip} / 1967$ ? Bagaimana perkembangan hukum waris pada masyarakat Karo dewasa ini? Jenis penelitian ialah penelitian empiris yang bersifat deskriptif analitis. Terjadi pergeseran hukum waris adat Karo pasca putusan MA Nomor.179K/SIP/1961 menyamakan hak anak laki-laki dengan anak perempuan, dan pasca putusan MA Nomor $100 \mathrm{~K} / \mathrm{SIP} / 1967$ yang menyatakan bahwa janda adalah ahli waris almarhum suaminya.

Kata kunci: hukum waris adat Karo, anak perempuan/janda, Putusan MA

\section{Introduction}

Till present, there is no national inheritance law nor legislation that specifically regulates inheritance. Dynamic law dynamics can be traced back from the ideas and policies in the past to fix the present and predict what will happen in the future. ${ }^{1}$ Indonesia is a nation that consists of various ethnic groups. For example Sumatra has Karo, Akit, Minangkabau and Batak ethnic groups, whereas in Sulawesi there are

$\Omega \quad$ This paper based on Penelitian Hibah Bersaing 2016 by contract number: 155/UN5.2.3.1/PPM/SP/2016, Fund's Source: DIPA Dirjen Dikti

Muazzin, "Hak Masyarakat Adat (Indigeneous People) atas Sumber Daya Alam: Perspektif Hukum Internasional", Padjadjaran Jurnal Ilmu Hukum, Vol. 1 No. 2, 2014, Bandung: Universitas Padjadjaran, page 4.
Buton, Bugis and Makassar. Hundreds of ethnic diversities cause different customary law from one to another. ${ }^{2}$

The implementation of adat law for indigenous people undoubtedly influences inheritance law. Inheritance law plays a significant role since the issue of inheritance is the thing people always experience. One's death would raise the question on how wealth legacy (if any) must be treated, to whom the property was transferred, and how the process is. These must

\footnotetext{
Agus Sudaryanto, "Aspek Ontologi Pembagian Waris dalam Hukum Islam dan Hukum Adat Jawa", Jurnal Mimbar Hukum, Vol. 22 No. 3, October 2010, Yogyakarta: Universitas Gadjah Mada, page 1.
} 
be regulated in the inheritance law. ${ }^{3}$ Beside the law of marriage, the inheritance law as part of the familial law plays a very important role, even decisive and reflects the familial system prevailing in the society. ${ }^{4}$

Basically there are three (3) types of inheritance law that still exist and live among society, first, inheritance law of Islam, as stipulated in Islamic inheritance jurisprudence; second, adat inheritance law, and third, inheritance Law of Civil Code. ${ }^{5}$ The legal pluralism does not only take place in Indonesia but also in majority of countries in African continent in which pluralistic national legal system is derived from customary law (religious law, especially in areas where Muslims make up the largest population), the colonial laws and legislation (both adopted from the colonial period and made by the Parliament after independence). ${ }^{6}$

To Karo people, boys are considered as the successor descent (clans), while married girls (by "honest") entered her husband's clan and disconnected from her own relatives/clan. To put simply, not all indigenous people have the qualified instruments as legal but they still have the traditional rights or indigenous rights based on historical relationships and the norms of long interaction. ${ }^{7}$ Conditions and rules have been obeyed for generations recently cause a sense of unfair and sparks disputes among heirs especially among girls and widows who had lost

3 Muh. Idris, "Implementasi Hukum Waris dan Pengajarannya Pada Masyarakat Kec. Poleang Tengah Kab. Bombana (Perbandingan Antara Hukum Adat, Hukum Islam dan Hukum Perdata)”, Jurnal Al- 'Adl, Vol. 8 No. 1, January 2015, Banjarmasin: Faculty of Law Universitas Islam Kalimantan, page 3 .

4 Anita Kamilah and M. Rendy Aridhayandi, "Kajian Terhadap Penyelesaian Sengketa Pembagian Harta Warisan Atas Tanah Akibat Tidak Dilaksanakannya Wasiat Oleh Ahli Waris Dihubungkan Dengan Buku II Kitab UndangUndang Hukum Perdata tentang Benda (Van Zaken)", Jurnal Wawasan Hukum, Vol. 32 No. 1, February 2015, Bandung: Sekolah Tinggi Hukum Bandung, page 4.

5 Akhmad Haries, "Analisis Tentang Studi Komparatif Antara Hukum Kewarisan Islam dan Hukum Kewarisan A dat", Jurnal Fenomena, Vol. 6 No. 2, 2014, Samarinda: Institut Agama Islam Negeri, page 1.

6 Muna Ndulo, "Customs, and Women's Rights", Jurnal African Customary Law, 2011, Cornell Faculty of Law Publications, page 87.

7 Rosmidah, "Pengakuan Hukum Terhadap Hak Ulayat Masyarakat Hukum Adat dan Hambatan Implementasinya", online-journal.unja.ac.id, Jambi: Faculty of Law Universitas Jambi, page 3. her husband, both widowed wife of the first, second and so on. The dispute is initially brought to runggun (deliberation) custom attended by Sembuyak, Senina, Sepemeren, Separibanen, Kalimbubu, ${ }^{8}$ but the girl side does not approve the Verdict of traditional justice that still uphold the principle that the son obtains a larger share than the girl does and so on. Then the girls propose for litigation in District Court by filing a lawsuit. At the end, the case has the legal effect that remained after proceeding to the Supreme Court marked by the Supreme Court Verdict No. $179 \mathrm{~K} / \mathrm{Sip} / 1961$ ruled in favor of Dem br. Sitepu cs. Verdict referred to confront the Karo adat inheritance laws by stating that the share of girls as an heir equals to boys and widows are entitled to inherit from the estate of her husband who died. ${ }^{9}$ Again, Jurisprudence Reg. 179 K/Sip/1961 dated October 23, 1961 stated that the Supreme Court considers a law that lives in Indonesia, so does in Tanah Karo, that girls and boys from a legacy of the deceased equally entitled to inherit the deceased's wealth. Supreme Court Verdict No. $100 \mathrm{~K} / \mathrm{Sip} / 1967$ governs that widow is the heirs along with her children. Similarly, the Supreme Court Verdict No. $100 \mathrm{~K} / \mathrm{Sip} / 1967$ dated June 14, 1968 states that: “... given the growth of today's society that is heading in the direction of equality between men and women and the establishment of a widow as heir has a jurisprudence embraced by Supreme Court RI and so on". In cultural practice, there are many Islamic society who prefer applying adat inheritance, eventhough sociologically, they are not indigenous people. ${ }^{10}$ Inheritance under adat law could occur during the life of the heir (who left). ${ }^{11}$ This aims to avoid disputes among members of

8 Yopita Arihta, "Kedudukan Anak Angkat Dalam Pewarisan Menurut Hukum Adat Batak Karo di Desa Ajibuhara Kecamatan Tiga Panah Kabupaten Tanah Karo", JOM Fakultas Hukum, Vol. II No. 1, February 2015, Riau: Faculty of Law Universitas Riau, page 11.

9 Sulistiyowati Irianto, 2005, Perempuan Dalam Pilihan Hukum, Jakarta, Yayasan Obor Indonesia, page 221-222.

10 M Firdaus, "Pembaharuan Hukum Waris Islam di Era Kontemporer", Istinbath, Jurnal Hukum Islam, Vol. 14 No. 1, June 2015, Mataram: Institut Agama Islam Mataram, page 3.

11 R Badri, 2005, Perkawinan Menurut Undang-Undang Perkawinan dan KUH Perdata, Amin:Surabaya, page 225. 
family. The division of inheritance is based on the intention to divide and share the rights of heirs. It becomes the heir's right since the death of the deceased so there is no reason to delay the division. ${ }^{12}$

Rehngena Purba said the Supreme Court Verdict is in fact in society is hardly implemented, the court's Verdict can only be executed by the parties to the dispute. ${ }^{13}$ The transformation of the cultural changes occur as the process of implementing new customs or traditions that are inconsistent with what was once believed. ${ }^{14}$

\section{Problems}

Based on the description in the background, the problem statements are formulated as follows. First, how is the Status of Daughter and Widow To His parents/ husband's inheritance at Karo People post Supreme Court Verdict No. $179 \mathrm{~K} / \mathrm{Sip} / 1961$ and Supreme Court Verdict No. $100 \mathrm{~K} / \mathrm{Sip} / 1967$; and second, how is the development of heritage elements in Karo people today.

\section{Research Methods}

This type of research is empirical research which is a descriptive analysis, the research shows the positions of girls and widows to the inheritance for their parents/husband at the Karo people post the Supreme Court Verdict No. $179 \mathrm{~K} / \mathrm{Sip} / 1961$ and Supreme Court Verdict No. $100 \mathrm{~K} / \mathrm{Sip} / 1967$, which describes the development of Karo Adat Inheritance Law, analyze the problems arising around Karo Adat inheritance Law in detail and subsequently draw con-

12 Asni Zubair, "Praktik Pembagian Harta Warisan Masyarakat di Kelurahan Macanang Kecamatan Tanete Riattang Barat", Jurnal Hukum Keluarga Islam, Vol. I No. 1, November 2014, Jombang: Universitas Pesantren Tinggi Darul 'Ulum Jombang, page 16.

13 Rehngena Purba, "Hukum Adat Dalam Yurisprudensi, This Paper presented on "Seminar Tentang Refitalisasi dan Reinterpretasi Nilai-nilai Hukum Tidak Tertulis dan Penemuan Hukum", was conducted on 28-30, 1978, in Makasar, Sulawesi Selatan, page 3

14 Andreas Jefri Deda and Suriel Semuel Mofu, "Masyarakat Hukum Adat dan Hak Ulayat di Propinsi Papua Barat sebagai Orang Asli Papua Ditinjau dari Sisi Adat dan Budaya; Sebuah Kajian Etnografi Kekinian”, Jurnal Administrasi Publik, Vol. 11 No. 2, October 2014, Bandung: Universitas Parahyangan, page 17. clusions and suggestions related to the results of the research. The population in this study is Karo People living in Karo regency while the respondents were determined by a "stratified random sampling". Data collection were done by literature study and interview, resulting in collection of primary and secondary data as expected. Then to obtain accurate data, assessment and coding were done to produce the data easier to read and analyzed. From the grouping of the data then it is analyzed by qualitative approach and then it is described how the phenomenon emerges and facts in the implementation of the Karo adat inheritance laws.

\section{Discussion}

Status of Daughter and Widow To His parents/ husband's inheritance at Karo People post Supreme Court Verdict No. 179 K/Sip/1961 and Supreme Court Verdict No. 100 K/Sip/ 1967

The legal system on inheritance in Indonesia is called plural due to co-governing legal systems. They comprise adat law, Islamic law, western law. These three legal system are applied by people simultaneously. Some apply adat law, some other apply Islamic law while the rest sometimes apply Western Civil Code. ${ }^{15}$ "Patrilineal societies as well as Batak Karo people, it is boys who become the heir, because the girls are outside its patrilineal original group once they got married". ${ }^{16}$ Some reasons or arguments strongly support the inheritance adat law of patrilineal people, so that only the boys have the right to inherit possessions of the heir to the deceased, while the daughter do not. It is based on the assumption "underestimate women position especially in Karo people, and Batak people in general". ${ }^{17}$ This assumptions are proven by: first, the dowry (tukur), indicating that women are sold; secondly, indigenous lakoman (levirat), which proves that women are inherited by the brother of her deceased husband; third,

15 Nur Aisah, “Tinjauan Hukum Tentang Kedudukan Janda Menurut Kitab Undang-Undang Hukum Perdata", Jurnal Ilmu Hukum Legal Opinion, Vol. $24^{\text {th }}$ Edition, 2014. Palu: Faculty of Law, Universitas Tadulako, page 1.

16 Soerjono Soekanto, 1981, Hukum Adat Indonesia, Rajawali, Jakarta, page 286

17 Ibid, page 65. 
women have no inheritance right; and fourth, the word "naki-naki" showed that women are illusive creatures, and others. ${ }^{18}$

The fact that the boy is the heir to the Karo people, influenced by several factors such as the first, male-based kinship. Girls cannot proceed blood line/kinship; second, within the household, the wife is not the head of the family. Children use the father's family name (surname). Wives are classified into husbands' clan; third, in the customs, a woman cannot represent the parents (his father) because she is classified into her husband's family members; fourth, in the customs, kalimbubu (male) are considered members of the family as a parent (mother); and fifth, if a divorce occurs, the children become husband's responsibility. The boy later becomes the heir of his father in both the customs and possessions.

Once a girl got married, she belongs to her husband's clan, called beru. There is a popular phrase among Karo people which explains well this condition; dilaki ngenca berhak (slechts zoona slechts gerechtigd), meaning that only boys are eligible. Then there is the phrase dilaki ngenca ibas pembagian (it is boys who have the rights from the division of inheritance), sidiberu la kenan (girls inherit none), diberu la banci erban taka (women are not able to assign portions), diberu la der kaipe (girls acquire nothing). ${ }^{19}$

Karo adat inheritance law governs that toward her late husband, the widow only serves firstly, supervisor or custodian of treasures who replaces the husband who had passed away in order to save the interests of the heirs; second, as long as the widow is still alive she is entitled to retain and make use of these treas-ures and are entitled to the results and benefits arising from it; and third, she was not allowed to reduce or to separate and sell the treasures.

18 Komari, "Eksistensi Hukum Waris di Indonesia: Antara Adat dan Syariat", Jurnal Asy-Syari'ah, Vol. 17 No. 2 August 2015, Bandung: Asosiasi Sarjana Syariah Indonesia (ASSYI) cooperated with Faculty of Sharia and Law Universitas Islam Negeri Sunan Gunung Djati Bandung, page 5.

19 Herman Slaats dan Karen Portier, 1992, Traditional Verdict Making and Law, Yogyakarta, Gadjah Mada University Press, page $74-75$.
The sales of inheritance can only be done if the child has received approval from Beru, senina and kalimbubu in the purposes of the first, for the burial cost of her late husband; second, the repair cost the house and medical treatment for children and children's education costs; third, marriage expenses for boy; and fourth, the life cost of the widow and her children. $^{20}$

These Rights will be void by itself when the widow had been excluded from her husband's family or the widow's new marriage with other man outside her late husband's family.

Karo adat inheritance law that embraces pure patrilineal system regulates that widows are not the heirs of her husband. ${ }^{21}$ Historically comparing to the parental community, the position of widow changes proven by the Verdict of the Raad van Justitie Batavia on 17-26 November 1939 which stated that "Essentially widow is not the husband's heir but she is entitled to receive income from the her husband's legacy in case of insufficient marital property. ${ }^{22}$ Treasures that cannot be passed just covers the original property, while under such circumstances widow could still carry the property acquired during marriage. The underlying legal basis in previous principle that the widow is not the heir of her late husband. Then, the widow more has better position. At this point, the widow is not her late husband's heir yet posses the legacy of her late husband until the widow dies or remarries. The word posses means that a widow may make use of her late husband's legacy, so her life is not displaced. For example, her late husband's legacy in the form of a house and a plot of rice field, then the widow could occupy the house and planted their fields and take the results of these fields. Widows shall not transfer these properties. The right of possession by a widow in parental communities results in legacy that may be not be divided or the implementation is delayed for a long time or only a portion which can be shared. Her late husband's abun-

\footnotetext{
Loc.cit

Soerjono Soekanto \& Yusuf Usman, Op.cit., page 25-26.

22 Hilman Hadikusuma, 1980, Hukum Waris Adat, Bandung, Alumni, page 98.
} 
dant estate is not fully distributes regarding widows who need it so her life is not displaced, otherwise if wealth of legacy is limited, as the examples above (just a house and a plot of rice field) then the division will be delayed, as well as to the joint property acquired during the marriage. ${ }^{23}$

\section{Development on Inheritance Elements of Karo People}

The example of disputes that occurs in the community, but was not brought to trial in the Court is the case of B. Sembiring Meliala in Ujung Village, Simpang Empat District, Karo Regency. He is a civil servant who works for the Civil District Court coming from a very modest family. His father used to work as staff in private companies. He is the $2^{\text {nd }}$ child of five; 3 males and 2 females. The parents fairly divided the inheritance according the Supreme Court Verdict No. 179/K/Sip/1961.

Case of K. Tarigan in Sumbul village, Sumbul District, Karo Regency. A man who works for a private company, coming from a middle-up family and has two women siblings, working in private companies as well. Parents divide the inheritance to both male and female, though did not know about the Supreme Court Verdict.

People who do not comply with the Supreme Court Verdict No. 179/K/Sip/1961 instead of ignorance and fears means degrading their adat law (Karo Adat Inheritance Law). It is illustrated in the following cases: in the case of P. Br. Bukit in Sumbul Village, Sumbul District, Karo Regency, a housewife who lived in Lau Gendek, her father of Karo people and her mother of Javanese, consisting of 3 women and 1 man in the family. The girls pursued study until High School while brother continued it to college. The inheritance is intended to boys only, while women earn pemere and the buat-buaten right.

Case of G. Br. Kaban in Ketaren Village Kabanjahe District of Karo Regency. As a self-

23 Eka Susylawati, "Kedudukan Janda Dalam Hukum Waris Adat Pada Masyarakat Parental”, Jurnal Al Ihkam, Vol. IV No. 2 December 2009, Pamekasan: STAIN Pamekasan, page 266 . employed person, Lau Cimba has 6 siblings; 4 men and 2 women, his father was a vegetable farmer and his mother is a housewife; both are elementary school graduate. The parent inheritance is unfairly distributed in which men earn more than girls by assuming that boys would be the successor of the clan while women joined her husband later. Daughters only own jewelry (pemere) and buat-buaten field (right of use throughout his life).

Case of $Z$. Sembiring that has passed away long time ago then J. br Tarigan, his wife died later. Br J. Tarigan (his mother) told them not to distribute the property before the grandchildren complete their studies. As time goes by, the female (child Beru) proposed that the inheritance is better distributed although the grandchildren have not completed their studies. Then they do so by the provisions; girls gained 1 part of field, the rest is for the boys. A house remains to be lived together (rumah perpulungen), then the empty unproductive land which is not divided but managed by the grandchildren to present and no dispute occurs.

The results of the data show that some people divide the inheritance according to Supreme Court Verdict No. 179/K/Sip/1961 in which menand women have equal right in inheritance, while others still apply Karo adat law. Nevertheless, there are some families who apply a combination of the Supreme Court Verdict No. 179/K/Sip/1961 and Karo adat law such as the following cases:

Case of T. br Sebayang in Rumah Kabanjahe Village District of Kabanjahe Kabanjahe. As a civil servant of Tanah Karo Regent Office, in the afternoon he went to the fields. Coming from a modest family of 5 members, 3 men and 2 women, his father- a junior high school graduate is a farmer helped by his mother who were graduated from junior high school and make mats. Girls gained field but it is not equally shared yet she earned the buat-buaten right.

The case of the division of the legacy was already fairly distributed between men and women, regardless the Supreme Court Verdict No. 179/K/Sip/1961 including the following. 
Case of $\mathrm{D}$. Br Sebayang in Ketaren Village Kabanjahe District of Karo, a housewife who had two little children and the husband was a farmer. Her father was a fruits farmer and her mother was housewife, a very modest family. They are only junior high school graduate. A family of 5 people; 3 males and 2 females. Parents divided the small amount of treasure equally for his children, male and female, although he actually did not know the Supreme Court Verdict.

Cases/ lawsuits brought to the Kabanjahe District Court and Kabanjahe Religious Court on the positions of the widow in her husband's legacy. Case Reg. No. 13/Pdt.G/2012/PN.Kbj: inheritance of the grandmother/ bolang was divided for widows and their children both from his first marriage and her second marriage. The late of Dingen Sitepu did the First marriage, Renggut br Milala (she died first than Dingen Sitepu), son: Mawen br Sitepu and Maju Sitepu (male/Plaintiff); and Second, Baget br Ginting, his son: Makekata Sitepu, Reh Malem br Sitepu, Sei br Sitepu, Rata Sitepu, Christina br Sitepu (Defendant). The sued treasure by Maju Sitepu (male) came from the late Dapet Sitepu (Bolang) and late Surat br Ginting (grandmother). Register Case No. 2/Pdt.G/2011/PA-KBJ (Wasiat wajibah was transferred to his son who converted to Christianity).

The point of this case is that the plaintiff files a lawsuit in order Defendant I (boys) and Defendant II (Wife) designated as the beneficiary of the biological father Plaintiff and Defendant I named Ngandi Ginting, who had died while Plaintiff (boys) who are Christians are designated as the wasiat wajibah recipient. The legal basis that non Muslim heirs do not inherit the Muslim heir is the hadith of Usamah bin Zaid, the Prophet Muhammad PBUH said which means: "A Muslim does not inherit a kafir (likewise) property and vice versa ". Similarly, Article 171 (b) and (c) Compilation of Islamic Law, states that the deceased and the heir must be Muslims. ${ }^{24}$

24 Azni, "Eksistensi Hibah dan Posibilitas Pembatalannya Dalam Perspektif Hukum Islam dan Hukum Positif di Indonesia”, An-Nida' Jurnal Pemikiran Islam, Vol. 40 No.
Case Reg. No. 2/Pdt.G/2011/PA Kbj stipulated its Verdict as follows: first, granted the plaintiff's favor; second, determined the heirs of the deceased Ngandi Ginting (died on August 28, 2010): Maisaroh binti Karo Sunggal (wife/ widow) and Eduardi Ginting bin Ngandi Ginting (boys); third, establish Jayanta Ginting bin Ngandi Ginting (boys) as the wasiat wajibah recipient from the late Ngandi Ginting as converting to Christianity.

Case of $\mathrm{Br} \mathrm{R}$ Sembiring, a teacher who had lost her husband with no children. The widow stayed with her late husband's relatives. It is advisable to widows to remarry, but she did not want to, so that the widow's husband still manages property and no matters.

Inheritance issue in Karo people has shifted (developed). Karo people already distributed their inheritance equally between man and women yet there are still many people who divide their inheritance under Karo adat law, some Karo communities also divide the inheritance according to mixture of customary law and Supreme Court Verdict No. 179/K/Sip/1961;it means that women are given the legacy of unequal portions comparing to men yet women are also given pemere (jewelry) when she married. Some parents gave the buat-buaten right (use rights to the land) from his brother that can only be cultivated throughout her life.

The Karo Adat Inheritance Law developed that now the widow had obtained the legacy of her late husband because she is the one who takes care of his children especially due to the influence of Islamic Law (faraidh). However, widows with no children, according to Karo adat law are not entitled to the legacy of her late husband (only incidental case may occurs; that the widow stayed with her late husband's relatives. Thus according to Karo adat law, the widow with no children will return to her family/ relatives.

\section{Conclusion}

2, July-August 2015, Pekanbaru: Lembaga Penelitian dan Pengabdian kepada Masyarakat (LPPM), Universitas Islam Negeri (UIN) Sultan Syarif Kasim Riau, page 5. 
The status of daughter and widows toward their parents/husband inheritance of Karo people post Supreme Court Verdict No. $179 \mathrm{~K} /$ Sip/1961 and Supreme Court Verdict No. 100 K/ Sip/1967 shows that the Karo people divide their inheritance by implementing a combination of Karo Adat Law and Supreme Court Verdict simultaneously. Besides the daughters inherit less portion than sons, they also got pemere and the buat-buaten right.

The development of inheritance adat law of Karo people today are descibed as follows. Parents of Tanah Karo assume that daughters are also their children, hence they have equal right to inherit their parents yet in different portion. In some areas, girls also receive pemere (provision such as gold, jewelry) and the buat-buaten right (right to use the field throught out her life yet disinheritable). Nevertheless, in some other areas if the girl had gained most of his parents land she did not obtain the buat-buaten right, but only get pemere. Many parents in Tanah Karo has divided his legacy during his lifetime to avoid potential disputes after they died.

\section{References}

Aisah, Nur. "Tinjauan Hukum Tentang Kedudukan Janda Menurut Kitab Undang-Undang Hukum Perdata". Jurnal Ilmu Hukum Legal Opinion. Vol. $24^{\text {th }}$ Edition. 2014 Palu: Faculty of Law. Universitas Tadulako;

Arihta, Yopita. "Kedudukan Anak Angkat Dalam Pewarisan Menurut Hukum Adat Batak Karo di Desa Ajibuhara Kecamatan Tiga Panah Kabupaten Tanah Karo". JOM Fakultas Hukum. Vol. II No. 1. Pebruari 2015. Riau: Faculty of Law Universitas Riau;

Azni. "Eksistensi Hibah dan Posibilitas Pembatalannya Dalam Perspektif Hukum Islam dan Hukum Positif di Indonesia". An-Nida' Jurnal Pemikiran Islam. Vol. 40 No. 2. July-August 2015. Pekanbaru: Lembaga Penelitian dan Pengabdian kepada Masyarakat (LPPM). Universitas Islam Negeri (UIN) Sultan Syarif Kasim Riau;

Badri, R. 2005. Perkawinan Menurut Undang-Undang Perkawinan dan KUH Perdata. Surabaya: Amin;

Firdaus, M. "Pembaharuan Hukum Waris Islam di Era Kontempore". Istinbath. Jurnal Hu- kum Islam. Vol. 14 No. 1. June 2015. Mataram: Institut Agama Islam Mataram;

Haries, Akhmad. "Analisis Tentang Studi Komparatif Antara Hukum Kewarisan Islam dan Hukum Kewarisan Adat". Jurnal Fenomena. Vol. 6 No. 2. 2014. Samarinda: Institut Agama Islam Negeri;

Hilman. 1980. Hukum Waris Adat. Bandung. Alumni;

Idris, Muh. "Implementasi Hukum Waris dan Pengajarannya Pada Masyarakat Kec. Poleang Tengah Kab. Bombana (Perbandingan Antara Hukum Adat. Hukum Islam dan Hukum Perdata)". Jurnal Al-'Adl. Vol. 8 No. 1. January 2015. Banjarmasin: Faculty of Law Universitas Islam Kalimantan;

Irianto, Sulistiyowati. 2005. Perempuan Dalam Pilihan Hukum. Jakarta: Yayasan Obor Indonesia;

Deda, Andreas Jefri and Suriel Semuel Mofu. "Masyarakat Hukum Adat dan Hak Ulayat di Propinsi Papua Barat sebagai Orang Asli Papua Ditinjau dari Sisi Adat dan BudayaSebuah Kajian Etnografi Kekinian". Jurnal Administrasi Publik. Vol. 11 No. 2. October 2014. Bandung: Universitas Parahyangan;

Kamilah, Anita dan M. Rendy Aridhayandi. "Kajian Terhadap Penyelesaian Sengketa Pembagian Harta Warisan Atas Tanah Akibat Tidak Dilaksanakannya Wasiat Oleh Ahli Waris Dihubungkan Dengan Buku II Kitab Undang-Undang Hukum Perdata tentang Benda (Van Zaken)". Jurnal Wawasan Hukum. Vol. 32 No. 1. February 2015. Bandung: Sekolah Tinggi Hukum Bandung;

Komari. "Eksistensi Hukum Waris di Indonesia: Antara Adat dan Syariat”. Jurnal Asy-Syari'ah. Vol. 17 No. 2. August 2015. Bandung: Asosiasi Sarjana Syariah Indonesia (ASSYI) cooperated with Faculty of Sharia and Law Universitas Islam Negeri Sunan Gunung Djati Bandung;

Muazzin. "Hak Masyarakat Adat (Indigeneous People) atas Sumber Daya Alam: Perspektif Hukum Internasional". Padjadjaran Jurnal Ilmu Hukum. Vol. 1 No. 2. 2014. Bandung: Universitas Padjadjaran;

Ndulo, Muna. "Customs. and Women's Rights". Journal African Customary Law. 2011. New York: Cornell Faculty of Law Publications;

Purba, Rehngena. Hukum Adat Dalam Yurisprudensi. This paper presented on "Seminar 
Tentang Refitalisasi dan Reinterpretasi Nilai-nilai Hukum Tidak Tertulis dan Penemuan Hukum". was conducted on 28-30. 1978. in Makasar. Sulawesi Selatan;

Rosmidah, "Pengakuan Hukum Terhadap Hak Ulayat Masyarakat Hukum Adat dan Hambatan Implementasinya". online Journal of Universitas Jambi. accessed on: onlinejournal.unja.ac.id. Jambi: Faculty of Law Universitas Jambi;

Slaats, Herman. dan Karen Portier. 1992. Traditional Verdict Making and Law. Yogyakarta. Gadjah Mada University Press;

Soekanto, Soerjono. 1981. Hukum Adat Indonesia. Jakarta: Rajawali;

Sudaryanto, Agus. "Aspek Ontologi Pembagian Waris dalam Hukum Islam dan Hukum Adat Jawa". Jurnal Mimbar Hukum. Vol. 22 No. 3. October 2010. Yogyakarta: Universitas Gadjah Mada;

Susylawati, Eka. "Kedudukan Janda Dalam Hukum Waris Adat Pada Masyarakat Parental”. Jurnal Al Ihkam. Vol. IV No. 2 December 2009. Mataram: Institut Agama Islam Mataram;

Zubair, Asni. "Praktik Pembagian Harta Warisan Masyarakat di Kelurahan Macanang Kecamatan Tanete Riattang Barat”. Jurnal Hukum Keluarga Islam. Vol. I No. 1. November 2014. Jombang: Universitas Pesantren Tinggi Darul 'Ulum Jombang. 